\title{
Cystectomy of Ovarian Borderline and Malignant Tumors for Fertility Sparing: Outcome of Seventeen Cases
}

Junko Wroblewski ${ }^{1,6}$, Miyoko Takita ${ }^{1}$, Haruka Eto ${ }^{1}$, Rikiko Yamamichi ${ }^{1}$, Tomoko Yoneda ${ }^{1}$, Daisuke Nishi ${ }^{1}$, Toshiaki Matsuura ${ }^{1}$, Tomoyoshi Maruyama $^{1}$, Greggory Wroblewski ${ }^{2}$, Seiya Kato ${ }^{3}$, Ayako Muta ${ }^{3}$, Shinsuke Sato ${ }^{3}$, Sakika Sanada ${ }^{4}$, Tomohiro Nakayama ${ }^{5}$, Daisuke Okamoto $^{5}$ and Kunihiro Sakai ${ }^{1}$.

${ }^{1}$ Department of Obstetrics and Gynecology, Saiseikai Fukuoka General Hospital

${ }^{2}$ Faculty of Languages \& Cultures, Kyushu University

${ }^{3}$ Department of Pathology, Saiseikai Fukuoka General Hospital

${ }^{4}$ Department of Pathology, Kurume University Faculty of Medicine

${ }^{5}$ Department of Radiology, Saiseikai Fukuoka General Hospital

${ }^{6}$ Department of Gynecology, Kyushu Central Hospital

Corresponding Author: Junko Wroblewski, Department of Obstetrics and Gynecology, Saiseikai Fukuoka General Hospital.

Received date: April 22, 2021; Accepted date: July 21, 2021; Published date: August 19, 2021

Citation: Wroblewski J. , Takita M. , Eto H. , Yamamichi R., Yoneda T. , Nishi D. , Matsuura T. , Maruyama T., Wroblewski G. , Kato S. , Muta A. , Sato S., Sanada S. , Nakayama T. , Okamoto D. and Sakai K. (2021) Cystectomy of Ovarian Borderline and Malignant Tumors for Fertility Sparing: Outcome of Seventeen Cases. J. Obstetrics Gynecology and Reproductive Sciences 5(6) DOI:10.31579/2578-8965/079

Copyright: () 2021, Junko Wroblewski, This is an open access article distributed under the Creative Commons Attribution License, which permits unrestricted use, distribution, and reproduction in any medium, provided the original work is properly cited.

\begin{abstract}
Background: Here we present a retrospective study of 17 cases in which the ovary on the affected side was spared in fertility-sparing surgery (FSS) during treatment for ovarian borderline malignant or malignant tumor. We determine that cystectomy is a suitable treatment for ovarian borderline tumors.

Methods: A retrospective observation study was conducted at Saiseikai Fukuoka General Hospital in Japan between April 2009 and September 2020. Our hospital experienced 89 cases of FSS during treatment for ovarian borderline or malignant tumor. Of those, there were 17 cases in which the ovary on the affected side was spared. We examined recurrent and pregnant cases by stage, preoperative diagnosis, intraoperative pathological diagnosis, postoperative pathological diagnosis, and adjuvant therapy.
\end{abstract}

Result: Of the 17, 12 cases were borderline malignant tumor, 4 were immature teratoma grade 1 (G1), and 1 case was endometrioid adenocarcinoma G1. Rapid intraoperative pathological diagnosis was conducted in 9 of the cases, and there were 6 in which surgical method was chosen based on the aforementioned results. Laparoscopic surgery was performed in 2 cases in which tumors were deemed benign via preoperative diagnosis, 2 cases of mature teratoma, and 2 in which borderline ovarian tumor was suspected. One (1) case of paraovarian cystecomy in a patient with history of multiple cesarean sections turned out to be serous borderline tumor. Postoperative treatment took place in only 1 case: endometrioid adenocarcinoma. There were 2 cases of recurrence, and 4 cases were eventually able to become pregnant naturally postsurgery. These pregnant cases included 1 in which serous borderline tumor recurred and we performed both cystectomy and lymphadenectomy, and one in which chemotherapy was performed after cyst enucleation for endometrioid adenocarcinoma G1.

Conclusion: At present, there is no clear policy for FSS in cases such as stage Ib in which there are bilateral tumors. Accordingly, in the current study a radiologist was consulted for preoperative diagnosis, and surgical method was chosen with a view towards possible borderline malignancy or malignancy. In cases where fertility preservation of the affected ovary is a high priority, it is crucial to clearly explain the possibility of recurrence to the patient. We also stress the importance of detailed consultation among the surgical team during rapid intraoperal frozen section pathological examination for making the appropriate decision to ensure fertility preservation mid-surgery.

Key words: cystectomy; ovarian borderline tumors; fertility-sparing surgery (FSS)

\section{Introduction}

Ovarian borderline tumors (BTs) are defined as tumors displaying a histology that is intermediate between malignant and benign, and because of their relatively low malignancy, have a reputation as rarely if ever leading to death even in the event of recurrence after a long lapse. In Japan, there has been an increasing annual trend of such cases $[1,2]$. The most common histological type are either serous, mucus, or serous mucous, and in Japan, mucus and serous constitute $57.7 \%$ and $20.4 \%$ of cases, respectively. The standard surgical approach for earlystage ovarian cancer consists of bilateral salphingooophorectomy in a complete staging procedure also consisting of peritoneal washing cytology, peritoneal biopsy and omentectomy for the detection of any suspicious implants. In contrast to the standard approach, fertility sparing surgery (FSS) utilizes peritoneal biopsy and unilateral salphingo-oophorectomy in addition to the complete surgical staging mentioned above [3]. FSS has 
been recommended for young women [3], but because bilateral onset of BTs is not uncommon and fertility sparing unilateral salphingo-oophorectomy and unilateral cystectomy are often selected, tumorigenesis on the remaining side often occurs. Malignant ovarian germ cell tumors are often young-onset, and fertility sparing must be considered in such cases accordingly. Furthermore, diagnosis of borderline malignant tumor or immature teratoma during preoperative examination is difficult, and there are many cases in which surgical method is based upon rapid intraoperal frozen section pathology midsurgery. FSS is performed first, and the necessity of secondary radical operation is considered after postoperative permanent section diagnosis. In the current study, we review cases at our hospital where FSS was performed in borderline malignant and malignant tumor patients, including recurrences as well as patients who eventually became pregnant.

\section{Materials and method}

A retrospective investigation was performed on 17 cases of cystectomy in FSS for patients of ovarian borderline and malignant tumors at our hospital between the period April 2009 and September 2020. Age at preoperative diagnosis, surgical procedure performed, frozen section and postoperative diagnoses, tumor stage, treatment, follow-up, recurrence and pregnancy were all noted.

\section{Results}

General characteristics for the 17 cases surveyed can be seen in Table 1. Median age at primary treatment was 26.2 years (range 16-33 years), and 16 of 17 had no reproductive history. Median follow-up until recurrence was 13 months (range 8-20 months). Three (3) of 17 cases involved the right ovary, 5 involved the left, and 9 were bilateral $(52.9 \%)$. Eight $(8)$ of the $17(47.1 \%)$ received laparoscopic surgery as primary treatment, and 6 of the 8 were judged benign during preoperative diagnosis. None of the 8 cases in the laparoscopic surgery group experienced recurrence (Table 2).

\begin{tabular}{|l|c|}
\hline \multicolumn{2}{|c|}{ Characteristics } \\
\hline Median age (range) & $26.2(16-33)$ \\
\hline Reproductive history & $1(5.9 \%)$ \\
\hline Yes & $16(94.1 \%)$ \\
\hline No & $13(8-20 \mathrm{months})$ \\
\hline $\begin{array}{l}\text { Follow up until recurrence, } \\
\text { Median (range) }\end{array}$ & \\
\hline & $3(17.6 \%)$ \\
\hline Tumor site & $5(29.4 \%)$ \\
\hline Right & $9(52.9 \%)$ \\
\hline Left & \\
\hline Bilateral & \\
\hline
\end{tabular}

\begin{tabular}{|c|c|}
\hline Surgery & \\
\hline Laparoscopic & $8(47.1 \%)$ \\
\hline Laparotomy & $9(52.9 \%)$ \\
\hline \multicolumn{2}{|l|}{ Preoperative diagnosis } \\
\hline \multicolumn{2}{|l|}{ Benign } \\
\hline Endometrial cyst & $2(11.8 \%)$ \\
\hline Ovarian cystadenoma & $3(17.6 \%)$ \\
\hline Mature teratoma & $4(23.5 \%)$ \\
\hline Borderline malignant & $6(35.3 \%)$ \\
\hline Malignant & $2(11.8 \%)$ \\
\hline \multicolumn{2}{|l|}{ Pathology } \\
\hline Serous borderline & $5(29.4 \%)$ \\
\hline Mucinous borderline & $2(11.8 \%)$ \\
\hline Seromucinous borderline & $1(5.9 \%)$ \\
\hline $\begin{array}{c}\text { Endometrioid } \\
\text { adenocarcinoma G1 }\end{array}$ & $1(5.9 \%)$ \\
\hline Not abailable & $8(47.1 \%)$ \\
\hline \multicolumn{2}{|l|}{ Postoperative diagnosis } \\
\hline Serous borderline & $5(29.4 \%)$ \\
\hline Mucinous borderline & $4(23.5 \%)$ \\
\hline Seromucinous borderline & $3(17.6 \%)$ \\
\hline $\begin{array}{l}\text { Endometrioid } \\
\text { adenocarcinoma G1 }\end{array}$ & $1(5.9 \%)$ \\
\hline Immature teratoma G1 & $4(23.5 \%)$ \\
\hline \multicolumn{2}{|l|}{ Stage } \\
\hline $\mathrm{Ia}$ & $2(11.8 \%)$ \\
\hline $\mathrm{Ib}$ & $1(5.9 \%)$ \\
\hline Ic1 & $10(58.9 \%)$ \\
\hline Ic2 & $1(5.9 \%)$ \\
\hline Ic3 & $2(11.8 \%)$ \\
\hline III & $1(5.9 \%)$ \\
\hline Adjuvant therapy & $1(5.9 \%)$ \\
\hline Recurrence & $2(11.8 \%)$ \\
\hline Pregnancy & $4(23.5 \%)$ \\
\hline
\end{tabular}

Table 1. . Patient demographics and clinical characteristics.

Table 2 displays the clinical characteristics for the 17 cases. Nine (9) were examined by frozen section pathology during surgery, and in 7 cases, surgical method was reconsidered based on frozen section diagnosis. Of those 7 cases, the frozen section diagnosis matched the permanent pathological diagnosis (postoperative diagnosis) (Table 2). 


\begin{tabular}{|c|c|c|c|c|c|c|c|c|c|c|c|c|}
\hline No & Age & G/P & site & Preoperative diagnosis & cytology & Surgery & Stage & $\begin{array}{ll}\text { Frozen } & \text { section } \\
\text { diagnosis } & \end{array}$ & Postoperative diagnosis & Treatment & status & $\begin{array}{lr}\text { Total } & \text { follow } \\
\text { up } & \text { (in } \\
\text { months) } & \\
\end{array}$ \\
\hline 1 & 23 & G0P0 & Bil & endometrial cyst, ruptured & positive & $\mathrm{BC}$ & $1 \mathrm{c} 2$ & SBT & SBT & $\mathrm{N}$ & NED & 135 \\
\hline 2 & 16 & G0P0 & $\mathrm{Rt}$ & mature teratoma & - & TLRC & $1 \mathrm{c} 1$ & - & immature teraroma G1 & $\mathrm{N}$ & NED & 91 \\
\hline 3 & 28 & G0P0 & Bil & BT & negative & $\begin{array}{lll}\text { LSO, } & \text { RC, } & \text { OMTx, } \\
\text { AppDx } & & \end{array}$ & $1 \mathrm{c} 1$ & MBT & MBT & $\mathrm{N}$ & NED & 81 \\
\hline 4 & 26 & G0P0 & Bil & bilateral ovarian cancer & positive & $\begin{array}{l}\text { RSO, LC } \\
\text { Peritoneal resection }\end{array}$ & $2 \mathrm{c}$ & MBT & $\begin{array}{ll}\text { MBT } & \text { desmoplastic } \\
\text { implant(+) }\end{array}$ & $\mathrm{N}$ & NED & 80 \\
\hline 5 & 22 & G0P0 & Bil & SBT or cancer & negative & RSO, LC & $1 \mathrm{c} 1$ & SBT & $\begin{array}{l}\text { seromucinous borderline } \\
\text { tumor }\end{array}$ & $\mathrm{N}$ & NED & 65 \\
\hline 6 & 33 & G0P0 & Bil & endometrial cyst, BT & positive & $\begin{array}{l}\text { LSO, RC, OMTx, } \\
\text { AppeDx, } \\
\text { Peritonial resection }\end{array}$ & $1 \mathrm{c} 3$ & 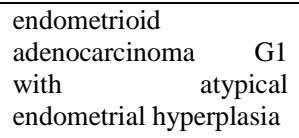 & $\begin{array}{ll}\text { endometrioid } & \\
\text { adenocarcinoma } & \text { G1 with } \\
\text { atypical } & \text { endometrial } \\
\text { hyperplasia } & \end{array}$ & $\begin{array}{l}\text { Y } \\
\text { GnRH antagonist } \\
+ \text { TC } 6 \text { cycles }\end{array}$ & NED & 55 \\
\hline 7 & 20 & G0P0 & $\mathrm{Lt}$ & mucinous cystadenoma & - & LC & $1 \mathrm{c} 1$ & - & MBT & $\mathrm{N}$ & NED & 53 \\
\hline 8 & 29 & G0P0 & Bil & seromucinous BT & negative & TLBC, OMTx & $1 \mathrm{c} 1$ & seromucinous BT & seromucinous BT & $\mathrm{N}$ & NED & 37 \\
\hline 9 & 26 & G0P0 & Bil & mature teratoma & - & TLBC & $1 \mathrm{c} 1$ & - & $\begin{array}{l}\text { Lt: immature teraroma G1 Rt: } \\
\text { mature teratoma }\end{array}$ & $\mathrm{N}$ & NED & 26 \\
\hline 10 & 28 & G0P0 & $\mathrm{Lt}$ & mucinous cystadenoma & - & TLLC & $1 \mathrm{c} 1$ & - & MBT & $\mathrm{N}$ & NED & 25 \\
\hline 11 & 19 & G0P0 & $\mathrm{Rt}$ & $\begin{array}{l}\text { mature teratoma with } \\
\text { torsion }\end{array}$ & - & TLRC & $1 \mathrm{c} 1$ & - & immature teraroma G1 & $\mathrm{N}$ & NED & 22 \\
\hline 12 & 30 & G0P0 & $\mathrm{Rt}$ & BT & negative & TLRC & $1 \mathrm{a}$ & SBT (minor component) & SBT(minor component) & $\mathrm{N}$ & NED & 19 \\
\hline 13 & 25 & G0P0 & $\mathrm{Lt}$ & $\begin{array}{lll}\begin{array}{l}\text { mature } \\
\text { torsion }\end{array} & \text { teratoma with } \\
\end{array}$ & - & TLRC & $1 \mathrm{c} 1$ & - & immature teraroma G1 & $\mathrm{N}$ & NED & 19 \\
\hline 14 & 29 & G6P2 & $\mathrm{Lt}$ & ovarian cyst & - & $\mathrm{LC}+(\mathrm{C} / \mathrm{S})$ & $1 \mathrm{a}$ & - & SBT & $\mathrm{N}$ & NED & 13 \\
\hline 15 & 32 & G0P0 & $\mathrm{Lt}$ & endometrial cyst & - & TLLC & $1 \mathrm{c} 1$ & - & seromucinous BT & $\mathrm{N}$ & NED & 7 \\
\hline 16 & 33 & G0P0 & Bil & $\begin{array}{l}\text { mature teratoma or cancer } \\
\text { suspected }\end{array}$ & negative & $\mathrm{BC}$ & $1 \mathrm{~b}$ & SBT & SBT & $\mathrm{N}$ & NED & 6 \\
\hline 17 & 26 & G0P0 & Bil & SBT, ruptured & positive & RSO, LC & $1 \mathrm{c} 3$ & $\begin{array}{l}\text { Lt: BT Rt: necrotic BT } \\
\text { with torsion }\end{array}$ & SBT & $\mathrm{N}$ & NED & 2 \\
\hline
\end{tabular}

\section{Abbreviations}

$G$ gravity, $P$ parity, $B i l$ bilateral, $L t$ left, $R t$ right, $B C$ bilateral cystectomy, $L C$ left cystectomy, $R C$ right cystectomy, $L S O$ left salphingo-oophorectomy, $R S O$ right salphingo-oophorectomy,

TL translaparoscopicsurgery, C/S caesarean section, OMTx omentectomy, AppeDx appendectomy, G1 grade 1, $N$ no, $Y$ yes, GnRH gonadotropin releasing hormone, $T$

$T C$ pacritaxel+carboplatin chemotherapy, NED no evidence of disease, BT borderline tumor, SBT serous borderline tumor, MBT mucinous borderline tumor 
Table 3 shows clinical characteristics for the 2 cases of recurrence. Case 1 experienced recurrence on the right ovary with peritoneum dissemination for which frozen section pathology displayed serous borderline tumor. Right salphingo-oophorectomy and omentectomy along with peritoneum and lymph node dissection were performed. Permanent pathology diagnosis revealed noninvasive implants and no metastasis, and for this reason we declined follow-up treatment after surgery. Case 4 originally displayed mucinous borderline tumor on both ovaries and desmoplastic implants. The patient experienced a recurrence on the left ovary eleven months later, and frozen section pathology revealed serous borderline tumor. We subsequently decided on left ovarian cystectomy only.

\begin{tabular}{|c|c|c|c|c|c|c|c|c|c|c|c|}
\hline No & $\begin{array}{l}\text { Primary tumor } \\
\text { site }\end{array}$ & Surgery & Stage & $\begin{array}{l}\text { Postoperative } \\
\text { diagnosis }\end{array}$ & Adjuvant & $\begin{array}{l}\text { Disease free after } \\
\text { primary treatment } \\
\text { (months) }\end{array}$ & $\begin{array}{l}\text { Recurrence } \\
\text { site }\end{array}$ & Second surgery & $\begin{array}{l}\text { Frozen diagnosis of } \\
\text { recurrent tumor }\end{array}$ & $\begin{array}{l}\text { Diagnosis of } \\
\text { recurrent } \\
\text { tumor }\end{array}$ & $\begin{array}{l}\text { Therapy after } \\
\text { second surgery }\end{array}$ \\
\hline 1 & Bil & $\mathrm{BC}$ & $1 \mathrm{c} 2$ & SBT & $\mathrm{N}$ & 20 & Rt ovary & $\begin{array}{l}\text { RSO, OMTx, } \\
\text { LNs \& peritoneal } \\
\text { resection }\end{array}$ & SBT & $\begin{array}{l}\text { SBT } \\
\text { non-invasive } \\
\text { inplant }(+)\end{array}$ & $\mathrm{N}$ \\
\hline 4 & Bil & $\begin{array}{l}\text { RSO, LC, } \\
\text { Peritonial } \\
\text { resection }\end{array}$ & $2 \mathrm{c}$ & $\begin{array}{l}\text { MBT } \\
\text { desmoplastic } \\
\text { implant (+) }\end{array}$ & $\mathrm{N}$ & 11 & Lt ovary & LC & MBT & MBT & $\mathrm{N}$ \\
\hline
\end{tabular}

\section{Abbreviations}

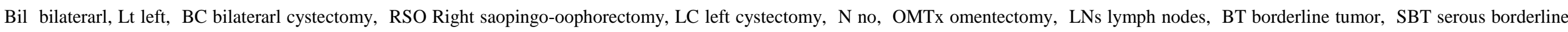
tumor, MBT mucinous borderline tumor 


\begin{tabular}{|c|c|c|c|c|c|c|c|c|c|c|c|}
\hline No & $\begin{array}{l}\text { Primary } \\
\text { tumor site }\end{array}$ & Surgery & Stage & $\begin{array}{l}\text { Postoperative } \\
\text { diagnosis }\end{array}$ & Adjuvant & $\begin{array}{l}\text { Disease free after } \\
\text { primary treatment } \\
\text { (months) }\end{array}$ & $\begin{array}{l}\text { Recurrence } \\
\text { site }\end{array}$ & Second surgery & $\begin{array}{l}\text { Diagnosis of } \\
\text { recurrent tumor }\end{array}$ & $\begin{array}{l}\text { Therapy } \\
\text { after second } \\
\text { surgery }\end{array}$ & Pregnancy after surgery \\
\hline 1 & Bil & $\mathrm{BC}$ & $1 \mathrm{c} 2$ & SBT & $\mathrm{N}$ & 20 & Rt ovary & $\begin{array}{l}\text { RSO, OMTx } \\
\text { LNs \&Peritonial } \\
\text { resection }\end{array}$ & $\begin{array}{l}\text { SBT } \\
\text { non-invasive } \\
\text { inplant (+) }\end{array}$ & $\mathrm{N}$ & $\begin{array}{l}\text { Y (naturally) } \\
\text { Preg 38W TVD }\end{array}$ \\
\hline 6 & Bil & RSO, LC & $1 \mathrm{c} 3$ & $\begin{array}{l}\text { endometrioid } \\
\text { adenocarcinoma } \\
\text { G1 }\end{array}$ & $\begin{array}{l}\mathrm{Y} \\
\text { GnRH } \\
\text { antagonist } \\
\quad+\mathrm{TC} 6 \text { cycles }\end{array}$ & & & & & & $\begin{array}{l}\text { Y (naturally) } \\
\text { Preg } 36 \mathrm{~W} \text { C/S }\end{array}$ \\
\hline 9 & Bil & TLBC & $1 \mathrm{c} 1$ & $\begin{array}{l}\text { Lt: immature } \\
\text { teraroma G1 } \\
\text { Rt: mature } \\
\text { teratoma }\end{array}$ & $\mathrm{N}$ & & & & & & $\begin{array}{l}\text { Y (naturally) } \\
\text { Preg 6W }\end{array}$ \\
\hline 16 & Bil & $\mathrm{BC}$ & $1 \mathrm{~b}$ & SBT & $\mathrm{N}$ & & & & & & $\begin{array}{l}\text { Y (naturally) } \\
\text { Preg } 15 \mathrm{w}\end{array}$ \\
\hline
\end{tabular}

\section{Abbreviations}

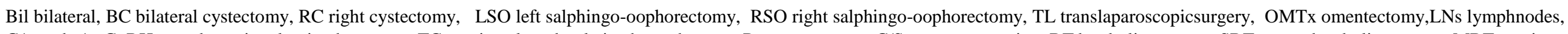

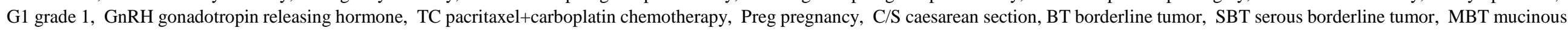

borderline tumor 
Of the 17 cases, 4 patients were able to become pregnant naturally without intervention. Table 4 shows the clinical characteristics for pregnant cases. Case 1 experienced recurrence twenty months after primary surgery but became pregnant fifty-five months after secondary surgery. Case 6 was bilateral ovarian cancer (endometrial adeonocarcinoma G1). Preoperative diagnosis was borderline malignant tumor, but the patient strongly desired fertility preservation even after consultation concerning the high risk of recurrence and possibility of death. During surgery, the attending physician and pathologist reviewed frozen section diagnosis with a view towards ovary preservation. Our pathologist judged the left ovarian cancer as more aggressive than the right and that the right ovarian endometrial adenocarcinoma G1 displayed a great deal of background hyperplasia. Subsequently, we decided upon right ovarian tumor cystectomy for fertility-sparing purposes. Following primary surgery, the patient was treated with 6 cycles (6 months) paclitaxel-carboplatine (PC) chemotherapy + gonadotropin-releasing hormone $(\mathrm{GnRHa})$. Only three months after primary treatment, the patient became pregnant (Figure 1). Case 9 became pregnant twenty-four months after primary surgery, and case 16 did so six months after primary surgery.

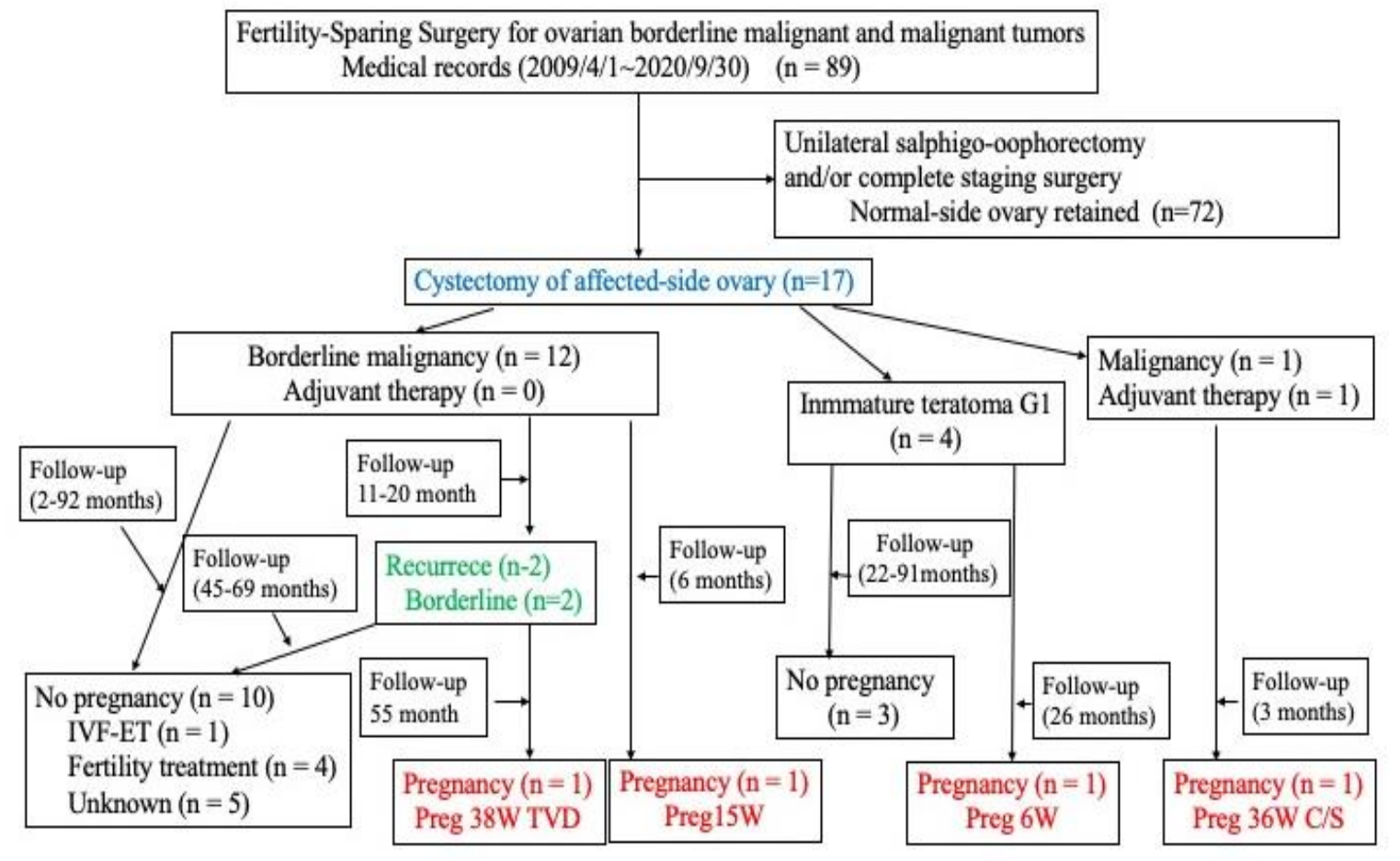

Figure 1. Flowchart of reproductive outcomes.

\section{Discussion}

In Japan, owing to a trend towards delayed marriage and pregnancy later in life, consideration of FSS in young patients with ovarian borderline malignant or malignant tumors is becoming increasingly important. Immature teratoma G1 has been classified by the WHO [4] as malignant and a two-tiered system has been adopted in which G1 is considered lowgrade and G2 and G3 as high-grade [2,3,4,5]. For G1 stage 1, adjuvant chemotherapy is often prescribed [6], and salphingo-oophorectomy is suggested by the National Cancer Institute (2020) [7]. If postoperative diagnosis reveals immature teratoma G1 stage 1 after cystectomy in which preoperative diagnosis was mature teratoma, recurrence will likely not be discovered without resection of the affected ovary, and there is still no consensus on whether an additional salphingo-oophorectomy should be performed in the case of G3 stage 1[8,9]. In our case, when preoperative diagnosis was mature teratoma we performed cystectomy, and when it was immature teratoma G1, we continued close observation. According to ESMO-ESGO guidelines[10], cystectomy of bilateral BTs is acceptable due to its insignificant effect on life prognosis, and recurring tumors are often borderline malignant. Because there are many cases of invasive cancers following the cystectomy of mucinous borderline tumors [6,11], salpingo-oophorectomy is recommended, and a standard surgical approach should be considered at the point when maintaining fertility is no longer the utmost priority. On the other hand, in the event of performing FSS for serous borderline tumor with invasive implant or residual tumor tissue, there are reports of recurrence of invasive cancer resulting in death[12]. Mid-surgery, peritoneal inspection, biopsy, and implant removal are necessary.

According to a Swedish national study [13], investigation of survival outcomes and long-term follow-up times reduces the risk of underestimating overall survival (OS) rates. In their particular cohort, the median time until death was 41 months (range 21-66), but BTs can appear up to 10 years later [6]. It has been mentioned by Xu et al [14] that close 
follow-up is important due to the high recurrence rates many years postdiagnosis.

In the current study, for Case 4 stage $2 \mathrm{c}$, we conducted a peritoneal examination and subsequent biopsy and dissection. We have yet to perform adjuvant chemotherapy because it was a non-invasive implant, and there has yet be a recurrence despite 80 months having passed at time of press. Case 1 recurred 20 months after primary surgery, and we performed salpingo-oophorectomy and omentectomy, as well as lymph node and peritoneal dissection. After 55 months passed, she was able to become pregnant naturally. For Case 6, BTs were suspected during preoperative examination, with FSS strongly desired after lengthy discussion with the patient and family members. We decided that even if frozen section pathology showed malignancy, we would first perform FSS, and if the permanent section pathology results came back malignant, we would then consider secondary surgery. Consequently, even though it was endometrioid adenocarcinoma G1, FSS was performed. Mid-surgery, the pathologist was consulted for determination on which tissue appeared more aggressive and/or which side could be saved, and cystectomy was performed on the right ovary. Even though post-surgical diagnosis was endometrioid adenocarcinoma G1, because the main part was atypical hyperplasia, the patient declined additional surgery. We then administered adjuvant chemotherapy, with 6 cycles of pacritaxel+carboplatin (TC therapy). To prevent chemotherapy-induced premature ovarian failure (POF), we used gonadotropin-releasing hormone antagonist (GnRHa) during chemotherapy, and 3 months postchemotherapy the patient became pregnant. For endometrioid borderline cases, the 5-year recurrence-free survival rate is significantly higher in cases of salphingo-oophorectomy than cystectomy[15]. Despite administration of chemotherapy, close follow-up will be necessary and possibly necessitate radical surgery later.

In the current study, the recurrence rate (11.8\%) was somewhat high but similar to previous published reports in which FSS was performed $[13,16,17]$. The pregnancy rate of $23.5 \%$ (4/17) was also consistent with previous reports $[13,16]$. Four (4) patients became pregnant naturally (Figure 1), with 13 yet to do so and 5 patients currently in fertility treatment. Concerning the use of GnRHa to protect from chemotherapyinduced POF, there have been a mixture of positive and negative reports in the literature $[18,19,20]$. Recently Demeestere I et al [21] suggested that there is no evidence for the benefit of GnRHa in preserving ovarian function and fertility. In case 7, we were not sure that GnRHa worked against POF, but after first menstruation following chemotherapy, she surprisingly became pregnant.

The current study is a retrospective examination of affected-ovary cystectomy, and the number of cases is admittedly limited. Nevertheless, here we highlight the importance of conducting joint discussion with pathologists, and in cases of suspected borderline malignancy or malignancy following review of preoperative diagnostic imaging and clinical findings, we perform laparotomy whenever possible and submit frozen section pathology mid-surgery. Even mid-surgery, we exchange detailed information with pathologists concerning laparoscopic findings and pathology when deciding upon a subsequent surgical approach. Radiologists, gynecologists, and pathologists also consult post-surgery, confirming a final diagnosis and deciding upon next course of action treatment-wise. With such a backdrop of cooperation and support, treatment featuring cystectomy in FSS will no doubt continue at our institution. While cases to present have consisted mainly of relatively short-term follow-up necessitating long-term follow-up in the future, we hope to hone treatment featuring cystectomy in FSS at our institution going forward.

\section{Conflict of Interest}

Statement: Authors declare there are no conflicts of interest associated with this manuscript.

\section{Patient Consent:}

This manuscript was deemed exempt from Saiseikai Fukuoka General Hospital Review Board.

Financial Disclaimer: None.

\section{Author Contributions:}

All authors were substantially involved in the acquisition of case report data, contributing to drafting of the manuscript, and critically revising the manuscript for important intellectual content.

\section{Reference}

1. Japan Society Obstetrics and Gynecology Gynecology committee. Annual report. Acta Obestetrica et Gynaecologica Japonica. (2018) ;70: 1372-1444.

2. Japan Society Obstetrics and Gynecology Gynecology committee. Annual report. Acta Obestetrica et Gynaecologica Japonica.( 2019); 71: 702-719.

3. Guidelines for treatment of ovarian cancer, fallopian tube cancer and primary peritoneal cancer: Japan Society Obstetrics and Gynecology Gynecologic Oncology. (2020)edition.

4. Kurman RJ, Carcahgiu ML, Herrington CS, Yong RHE. WHO classification of Tumors of Female Reproductive Organs, $4^{\text {th }}$ edithion. Lyon:IARC 2014.

5. O'Conor DM, Norris HJ. (1994) The influence of grade on the outcome of stage I ovariani Immature (malignant) teratomas and reproductibity of grading. Int J Gynecol Pathol.;13:283289.

6. Gershenson DM.(2007) Management of ovarian germ cell tumors. J Clin Oncol ;25:2938-2943.

7. NCI ovarian germ cell tumors treatment (PDQ) Health professional Version.

8. Cushing B, GillerR, Albin A, Cohen L, Cullen J,Hawkins E,et al.(1999) Surgical resection alone is effective treatment for ovarian immature teratoma in children and adolesents: a report of the pediatric oncology group and the children's cancer group. Am J Obest Gynecol; 181:353-358.

9. Marina NM, Cushing B, Giller R, Cohen L, Lauer SJ, Ablin A et al. (1999) Complete surgical excision is effective treatment for children with immature teratomas with malignant elements: A Pediatric Oncology Group Intergroup Study. $J$ Clin Oncol; $17: 2137-2143$.

10. ESMO-ESGO Ovarian Cancer Consensus Conference Working Group. ESMO-ESGO consensus conference recommendations on ovarian cancer; Pathology and molecular biology, early and advanced stage, borderline tumors and recurrent disease. Ann Oncol (2019);30(5):672-705.

11. Uzan C, Kikpayam M, Ribassin-Majed L, Gouy S, Bendifallah S,Cortez A. et al.(2014) Influence of histological subtypes on the risk of an invasive recurrence in a large series of stage I borderline ovarian tumor including 191 conservative treatments. Ann Oncol;25:1312-1319.

12. Du Bois A, Ewald-Riegler N, de Gregorio N, Reuss A, Mahner S, Fotopoulpu C. et al. Borderline tumors of the ovary:A cohort study of the Arbeitsmeinschaft Gynakologische Onkologie (AGO) Study Grou18p. Eur J Cancer 2013;49:1905-1914. 
13. Johansen G, Dahm-Kahler P, Staf C, Floter RA, RodriguezWallberg KA. (2020) Productive and obstetrical outcomes with the overall survival of fertile-age women treat with fertilitysparing surgery for borderline ovarian tumors in Sweden: A prospective nationwide population based study. Fertil Steril; Sep 22; S0015-0282

14. Mengwei Xu, Bowei Wanf, Yonghua Shi. (2020) Bordrline tumor in the pediatric and adolescent population: A clinopathologic analysis of fourteen cases. Int J Clin Exp Pathol;13(5):1053-1059.

15. Jia SZ, Zhang JJ, Liang ZY, Yang JJ, Xiang Y, Jia CW, Leng JH.(2018) Safety and fertility outcomes after the conservative treatment of endometrioid borderline ovarian tumors.BMC Cancer; $18: 1160$.

16. Chevrot A, Pouget N, Bats AS, Huchon A, Guyon F, Chopin N, et al .2020) Fertility and prognosis of borderline ovarian tumor after conservative management: Rwsult of the multicentric OPTIBOT study the GINECO \& TMRG group. Gynecol Oncol; 157:29-35.

17. Satoh T, Hatae M, Watanabe Y, Yaegashi N, Ishiko O, Kodama S.et al.(2010) Outcome of fertility-sparing surgery for stage I epithelial ovarian cancer: A proposal for patient selection. J Clin Oncol; 28(10):1727-1732.

18. Blumenfeld $\mathrm{Z}$, Patel $\mathrm{B}$, Leiba R, Zuckerman $\mathrm{T}$. (2012)Gonadotropin-releasing hormone agonist may minimize premature ovarian failure in young women undergoing autologous stem cell autologous stem cell transolantation. Fertil Steril;98:1266-1270.

19. Demeestere I, Breice P, Peccatori FA,(2013). Gonadotropinreleasing hormone agonist for the prevention of chemotherapynduced ovarian failuar in patients with lymphoma: 1 year follow up of prospective randomized trial. J Clin Oncol;31:903-909.

20. Lambertini M, Boni 1, MichelottiA,(2015) GIM Study Group. Ovarian suppression with triprorelin during adjuvant breast cancer chemotherapy and long-term ovarian function, pregnancies, and disease-free survival: A randomized clinical trial. JAMA.;314:2632-40.

21. Demeestere I, Brice P, Peccatori FA, Kentos A, Dupuis J, Zachee. P et al(2016). No evidence for the benefit of gonadotropin-releasing hormone agonist in preserving ovarian function and fertility in lymphoma survivors treated with chemotherapy: Final long-term report of a prospective randomized trial. J Clin Oncol;34(22):2565-2574

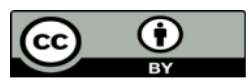

This work is licensed under Creative Commons Attribution 4.0 License

\section{To Submit Your Article Click Here: Submit Manuscript}

DOI: $10.31579 / 2692-9406 / 069$
Ready to submit your research? Choose Auctores and benefit from:

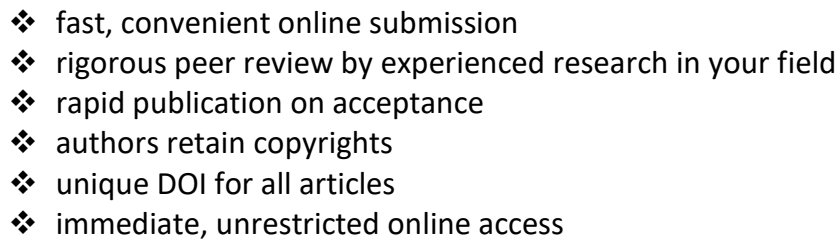

At Auctores, research is always in progress.

Learn more www.auctoresonline.org/journals/obstetrics-gynecologyand-reproductive-sciences 